\title{
Analysis of Recruitment System and Effective Selection for Front-Line Staff Outsource at Pt Garuda Indonesia (Persero) TBK
}

\author{
Bobby Pratama Saragih ${ }^{1}$, Harmein Nasution ${ }^{2}$, Iskandarini ${ }^{2}$ \\ ${ }^{1,2}$ Master of Management Study Program on Postgraduate School of University of Sumatera Utara \\ Corresponding Author: Bobby Pratama Saragih
}

\begin{abstract}
PT Garuda Indonesia (Persero) TBK is a stateowned company whose business focus is transportation services pax and cargo. In carrying out its business processes, the Garuda Indonesia Company has cooperation with PT Perdana Perkasa Elastindo (Persaels) in providing outsourced labor for front-line staff. The performance evaluation data of the frontline outsource staff stationed at Garuda Indonesia Medan Branch for the last 3 years (2015, 2016 and 2017), it was found that around $40 \%$ of the total front-line staff did not show good performance according to the company's needs. The purpose of this research is to identify the factors exist in the dimensions of the recruitment and selection system that are constraints, and formulate an effective recruitment process design and selection for outsourced front-line staff by outsourced service providers. The requirements of front-line staff met with the company needs as outsourced service users. The data analysis used descriptive qualitative technique. The results of the research on several factors from the existing recruitment and selection dimensions indicate that the factors of Job description, Job Requirements, Sources of recruitment, interview process and consistency in the implementation of the selection test are factors that become obstacles in producing competent outsourced front-line staff according to the needs of the company PT Garuda Indonesia ( Persero) TBK.
\end{abstract}

Keywords: Recruitment system, front-line staff outsource, PT Garuda Indonesia (Persero) TBK

\section{BACKGROUND}

Various types of companies are currently implementing the Outsourcing work system. Among them are companies engaged in Industry, Hospitality, Banking, Insurance, Telecommunications, Retail, and others. Referring to Indonesian Law No. 13 of 2003 concerning manpower, this outsourcing work system is applied to types of support work that are not directly related to the company's core business. The level of position that is outsourced is also the level of staff below, although there are also outsourced employees who are managed managerially. However, it is usually done in a work with a certain time frame or project.

Wijaya (2008) explains that outsourcing is the process of transferring jobs and services to third parties, in this case an outsourcing company. Outsourcing also means efforts to get experts and reduce the burden and costs of the company in improving the company's performance so that it can continue to be competitive in facing global economic and technological developments by handing over the company's activities to other parties as stipulated in the contract. The outsourced labor recruitment system is very relative and actually not much different from the employee recruitment system in general. Starting from the job application process, filling out registration forms and written test procedures to the interview process, and conducting medical checkups, according to the applicable procedures. The difference is, 
these employees are recruited by outsourced service providers, not by service user companies. By an outsourced service provider company, these employees will be sent to companies (business partners / service users) that need them. So, the person is actually managed by an outsourced service provider company, but will later work for the service user company.

Recruitment is defined as a series of activities carried out in a planned manner, in order to obtain prospective employees who meet the requirements required by a certain position required by an organization (Sirait, 2006). Therefore, recruitment is an important issue for an organization or company in terms of labor procurement, including in the recruitment process for employees by an outsourcing company. If the recruitment process is successful, or in other words, many applicants submit their applications, then the company's chances of getting good employees will be even wider, because the company will have many of the best choices of potential applicants. Effective recruitment requires the availability of accurate and continuous information regarding the number and qualifications of individuals required to carry out various jobs within the company. Recruitment activities will eliminate applicants who are not quite right and focus their abilities on candidates who will be called back.

One of the companies that use outsourcing labor services is PT Garuda Indonesia (Pesero) Tbk Medan branch office, which is in the fulfillment of frontline staff such as ticketing staff, reservation staff, customer service and service support. With the number of personnel needed around 42 people. Some of the problems that have been faced are the frequent complaints and bad reports about the performance of front-line staff placed by vendors who provide outsourcing services at PT Garuda Indonesia (Persero) Tbk Medan Branch. This has an effect on the amount of front-line staff turnover at Garuda Indonesia (Persero) Tbk and the increase in training costs. The magnitude of the complaints submitted by PT Garuda Indonesia, provided a separate initiative to conduct internal evaluations of the performance of front-line staff placed by vendors in the last three years (2015-2017).

Table 1. Results of Internal evaluation of front-line Staff of PT Garuda Indonesia Medan Branch

\begin{tabular}{|l|l|l|l|}
\hline RESULT & $\mathbf{2 0 1 5}$ & $\mathbf{2 0 1 6}$ & $\mathbf{2 0 1 7}$ \\
\hline Pass the test & $55 \%$ & $31 \%$ & $55 \%$ \\
\hline Didn't pass the test & $45 \%$ & $69 \%$ & $45 \%$ \\
\hline
\end{tabular}

The survey results showed the large portion of front-line staff employees that were not in accordance with what was expected by PT Garuda Indonesia (Persero) Tbk. This is due to many factors, especially the non-compliance of the qualifications required by PT Garuda Indonesia with frontline staffs placed by vendors of outsourcing labor service provider.

\section{Recruitment}

Recruitment according to Harmein Nasution (2005) is a decision about where and how to find prospective workers, at the right time to apply according to the position required by the organization, both from within and outside the organization, as stipulated in hr planning. Ivancevich (2001) added that recruitment relates to activities that affect the number and type of applicants, whether the applicant then accepts the job offered. According to Mathis and Jakson (2001) recruitment is a process that results in a number of qualified applicants for employment in a company or organization. This is in line with hasibuan opinion (2008) stated that recruitment is an effort to find and influence the workforce, in order to apply for job openings in the organization / company.

\section{Selection}

Rivai (2011) explained that selection is an activity in HR management that is carried out after the recruitment process is completed. This has accumulated a number of applicants who are eligible to then be selected which can be assigned as employees in a company. This selection 
process is called selection. Furthermore, according to Simamora (2004) said selection is the selection process of a group of applicants who most meet the selection criteria for positions available in a company. Meanwhile, according to Teguh (2009) explained that selection is a process consisting of several specific steps of some of the most suitable groups of applicants and meet the requirements for a particular position.

\section{Outsourcing}

According to Jehani (2008), that outsourcing is a form of delivery of a particular work of a company to a third party carried out with the aim of reducing

\section{Conceptual Framework}

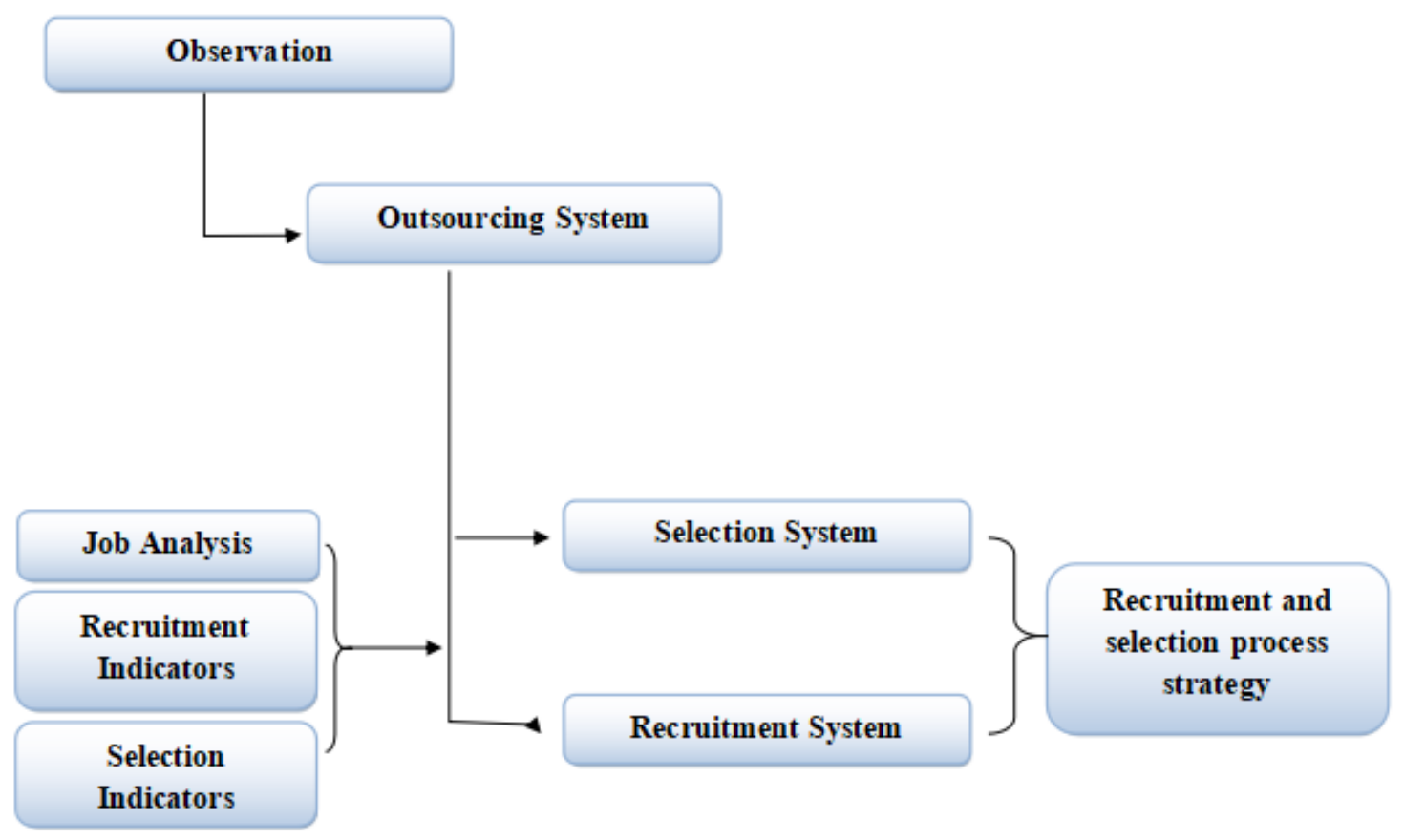

Figure 1. Conceptual Framework

The process flow of this research is conducted by:

1. Observation This research uses observation method because this research observes directly about the process of recruitment and selection implementation at the research site, namely at PT Persaels as an outsourcing labor provider company PT Garuda the burden of the company. So outsourcing is a form of employment agreement between the employer company (user) with the company provider labor (vendor), where the employer company asks the employer to provide the labor provider to provide the labor necessary to work in the employer company From some experts' opinions above it can be concluded that outsourcing is a form of employment agreement between the employer company and the outsourcing company, where the employer company asks the outsourcing company to provide the necessary labor to work in the employer's company accompanied by paying a certain wage or salary as promised by the parties. 
3. Making Research Report The results of research report making is through the processing of data from interviews, documentation and observation results where later the data will be analyzed.

\section{RESEARCH METHODS}

This research is a type of field research with qualitative approach. While this research is descriptive, the data collected takes the form of words or pictures rather than numbers. This research was conducted at PT Persaels as an outsourcing service provider of PT Garuda Indonesia (Persero) Tbk. The research period lasted for 4 (four) months starting from September 2016 to January 2017. Data collection techniques through Focus Discussion Group (FGD) with Branch managers, Managers and staff in HRD units, as well as other employees who are related to the information needed by researchers and data retrieval from existing documents in the form of records, transcripts, books, scientific journals, newspapers, magazines, websites and others.

Once the data is obtained the next step is to perform data analysis. All data obtained either by interview, documentation or observation results are processed / analyzed to achieve the final objectives of the research. In this study the author used qualitative descriptive data analysis techniques, namely data analysis techniques by describing the objective condition of the research object and deciphering it in the form of sentences based on primary data and secondary data.

\section{RESULTS AND DISCUSSION Recruitment System}

Based on the data obtained from the results of FGD that has been done that the recruitment system in the company PT Persaels is an open system, where when there is a front-line staff request from a client company, PT Garuda Indonesia (Persero) Tbk. PT Persaels will conduct analysis and description of the position to determine the required position requirements. So far, the client has not provided a clear job description for frontline staff positions. After determining the requirements of the position, PT Persaels will immediately make a flyer or advertisement on the official website of PT Persaels in order to attract the attention of job seekers. In the leaflets and advertisements, PT Persaels informs the required job requirements and location information of the placement company. In the recruitment process itself, the obstacles that become the main obstacle factors in the effectiveness of the recruitment process at PT Persaels is due to the lack of interest in job seekers and the lack of employee databases that meet the needs of the job requirements desired by the client company. This causes the frequent inhibition of PT Persaels and past the deadline of fulfillment of labor as provided by the client.

\section{Selection System}

Based on the data obtained from the results of FGD that has been done that the selection system in the company PT Persaels is varied according to the nature and needs of the client company. There are some clients who use the job application acceptance system - candidate calling test/interview - then hired/reject, and there are also some clients who still use the client's internal recommendations.

In the selection process itself, the obstacle that becomes the main obstacle factor in the effectiveness of the selection process at PT Persaels to meet the needs of the workforce at PT Garuda Indonesia (Persero) Tbk is often not carried out the initial interview process of prospective workers by the internal party of PT Persaels. This is done because PT Persaels assumes that if the candidate is considered appropriate then it can be directly handed over to the client, PT Garuda Indonesia (Persero) Tbk to be determined to be accepted or aborted from the selection process. Another obstacle that contributes small to the inhibition of the effectiveness of the selection process itself is the frequent 
Bobby Pratama Saragih et.al. Analysis of recruitment system and effective selection for front-line staff outsource at Pt Garuda Indonesia (Persero) TBK.

debate between PT Persaels and PT Garuda Indonesia (Persero) Tbk regarding the suitability of prospective workers to be placed.

\section{CONCLUTION}

1. Several factors that cause the low effectiveness of the recruitment system and selection of outsource front-line staff at PT Persaels to be placed in PT Garuda Indonesia (Persero) Tbk, namely:

a. The absence of information about front-line staff job description by PT Garuda Indonesia (Persero) Tbk to front-line staff resource provider vendor

b. Determination of position requirements that are not detailed based on job description and frontline staff needs expected by PT Garuda Indonesia (Persero) Tbk

c. Limited media placement of job advertisements and limited data of prospective front-line staff workers in the database PT Persales

d. Inconsistent process and stages of selection tests on prospective frontline staff candidates sent to PT Persaels users namely PT Garuda Indonesia (Persero) Tbk

2. The design of an effective recruitment and selection process for PT Persaels in obtaining outsource front-line staffs in accordance with the needs of PT Garuda Indonesia (Persero) Tbk is to Determine a clear job description for front-line staff positions, then Determine the required position requirements for front-line staff positions in accordance with the job description, then Assign / Find the source of applicants for front-line staff positions in accordance with the requirements of the position, and make improvements to the stages / design of the selection system.

Acknowledgement: None

\section{Source of Funding: None}

\section{REFERENCES}

1. Amin wijaya tunggal, 2008, Outsourcing konsep dan kasus, Harvarindo, Jakarta, Hal. 11.

2. Ambar, Teguh, Sulistiyani, Rosidah, 2009, Manajamen Sumber Daya Manusia. Yogyakarta: Graha Ilmu

3. Bangun, Wilson. 2012. Manajemen Sumber Daya Manusia.Jakarta: Erlangga.

4. Hasibuan, Malayu S. P. 2008. Manajemen Sumber Daya Manusia. Jakarta: PT. Bumi Aksara

5. Handoko T. Hani, 2008, Manajemen Personalia dan Sumber Daya Manusia, edisi kedua, Penerbit: BPFE, Yogyakarta

6. Hasibuan , Malayu S.P. 2002. Manajemen Sumber Daya Manusia. Bumi Aksara. Jakarta.

7. Ivancevich, John M. 2001, Human Resource Management, New York: Mc. Grow - Hill Companie

8. Ibrahim, Zulkarnain. 2005.Praktek Outsourcing Dan Perlindungan Hak-Hak Pekerja .Simbur Cahaya No. 27 Tahun X Januari 2005

9. Justine, T. Sirait,2006, Memahami aspekaspek Pengelolaan Sumber daya manusia dalam organisasi, Grasindo, Jakarta. Hal 5657.

10. Jehani Libertus, 2008 Hak-Hak Karyawan Kontrak, Forum sahabat, Jakarta,

11. Mathis. Robert I, Jackson John H. 2001. Manajemen Sumber Daya Manusia, Jakarta: Salemba Empat.

12. Nasution, harmein. 2005. Proses pengelolaan Sumber Daya Manusia, Medan : USU Press

13. Nasution, harmein. 2015. Pengelolaan Modal Manusia, Medan : USU Press

14. Republik Indonesia. 2003. Undang-undang No. 13 Tahun 2003 tentang Ketenagakerjaan, Jakarta.

15. Rivai, Veithzal, (2011). Manajemen Sumber Daya Manusia Untuk Perusahaan Dari Teori Ke Praktek. PT. RAJAGRAFINDO PERSADA, Jakarta.

16. Rivai, Veithzal, 2009, Manajemen Sumber Daya Manusia untuk Perusahaan, edisi kedua, Penerbit : Rajawali Pers, Jakarta.

Conflict of Interest: None 
Bobby Pratama Saragih et.al. Analysis of recruitment system and effective selection for front-line staff outsource at Pt Garuda Indonesia (Persero) TBK.

17. Simamora, Henry, 1997, Manajemen Sumber Daya Manusia, Yogyakarta; STIE YKPN.

18. Simamora, Henry, 2004, Manajemen Sumber Daya Manusia,Edisi Ketiga, Cetakan Pertama, Bagian Penerbitan STIE YKPN, Yogyakarta

19. Siagian, Sondang P. (2006). Manajemen sumber daya manusia. Jakarta : PT Bumi Aksara

20. Simmamora, Henry (2006). Manajemen sumber daya manusia . Yogyakarta : STIE YKPN

21. Susilo Martoyo, 2006, Manajemen Tenaga Kerja Rancangan Dalam Pendayagunaan Dan Pengembangan Unsur Tenaga Kerja, Sinar Baru,Bandung
22. Keputusan Menteri Tenaga Kerja dan Transmigrasi No.Kep-101/Men/VI/2004 tentang Tata Cara Perizinan Perusahaan Penyedia Jasa Pekerja/Buruh

23. Yasar,I.(2012).Outsourcing tidak akan pernah dihapus,Penerbit: Penerbit pelita fikir Indonesia

How to cite this article: Saragih BP, Nasution H, Iskandarini. Analysis of recruitment system and effective selection for front-line staff outsource at $\mathrm{Pt}$ Garuda Indonesia (Persero) TBK. International Journal of Research and Review. 2021; 8(5): 187-192. DOI: https://doi.org/10. 52403/ijrr.20210526 